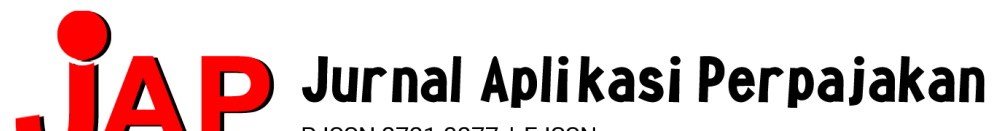

Volume 1 Nomor 2

P-ISSN 2721-3277 | E-ISSN

November 2020

\section{STUDI PELACAKAN ALUMNI PROGRAM STUDI D3 PERPAJAKAN FAKULTAS EKONOMI UNIVERSITAS MATARAM PERIODE WISUDA $2014-2018$}

\author{
Abdul Manan \\ Fakultas Ekonomi dan Bisnis Universitas Mataram \\ abdmanan@unram.ac.id \\ I Dewa Ketut Yudha S \\ Fakultas Ekonomi dan Bisnis Universitas Mataram \\ dewayudha1229@gmail.com \\ Siti Fatimah \\ Fakultas Ekonomi dan Bisnis Universitas Mataram \\ SitiFatimah@unram.ac.id
}

\begin{abstract}
ABSTRAK
Penelitian ini bertujuan untuk menganalisis 1). Bagaimana gambaran tentang profil lulusan alumni Prodi D3 Perpajakan (lama kuliah Alumni, Masa tunggu untuk mendapatkan pekerjaan pertama), 2) Bagaimana Tanggapan pengguna Alumni Prodi D3 Perpajakan fakultas ekonomi dan bisnis Universitas Mataram.

Metode penelitian dalam penelitian ini menggunakan metode deskriptif evaluatif. Subjek penelitian adalah Prodi D3 Perpajakan Fakultas Ekonomi dan Bisnis Universitas Mataram tahun tahun wisuda 2016-2018 sebanyak 60 orang alumni. Teknik analisis data yang digunakan dalam penelitian ini adalah analisis deskriptif dengan pendekatan kuantitatif untuk memberi gambaran yang berkaitan dengan profil lulusan atau alumni Prodi D3 Perpajakan Fakultas Ekonomi dan Bisnis Universitas Mataram

Hasil penelitian menunjukkan bahwa hampir seluruh (95 \%) alumni Prodi D3 Perpajakan menempuh masa studi tepat waktu sesuai yang dicanangkan oleh lembaga Prodi D3 perpajakan yaitu 3 tahun. Hal ini menunjukkan keberhasilan prodi D3 Perpajakan dalam mengelola prodi khususnya pada bidang pendidikan. Masa tunggu alumni prodi D3 Perpajakan untuk memperoleh pekerjaan pertama juga sebagian besar relatif singkat, dimana 75 persen dari keseluruhan alumni prodi D3 Pajak dapat memperoleh pekerjaan pertama kurang dari 6 bulan bahkan ada beberapa diantaranya mempunyai masa tunggu 0 tahun. Namun demikian bila dilihat relevansi bidang keahlian yang mereka miliki dengan bidang pekerjaan yang diperolehnya ternyata masih banyak yang tidak sesuai. Hal ini tentu saja akan berdampak pada lambatnya proses pengembangan diri mereka. Penilaian pengguna terhadap kinerja alumni prodi D3 Pajak dilihat dari 7 kriteria kinerja, hampir semua mendapat penilaian baik. Kecuali pada kriteria kemampuan bahasa inggris yang masih kurang dan sedikir masalah pada kemampuan penggunaan IT.
\end{abstract}

Kata kunc: Profil, Alumni, D3 Perpajakan, Pengguna

\section{PENDAHULUAN}

Keberhasilan sebuah institusi pendidikan dalam melaksanakan proses belajar mengajar, tergambar dari sejauh mana pengamalan ilmu yang diperoleh pada saat kuliah dapat bermanfaat bagi masyarakat ,khususnya bagi dunia kerja. Hal ini sejalan dengan salah satu tujuan pembelajaran agar anak didiknya dapat berguna serta bermanfaat dalam menyumbangkan ilmu keahliannya sesuai dengan bidangnya. Secara umum penyelenggaraan perguruan tinggi di Indonesia bertujuan untuk 
menyiapkan sumberdaya manusia yang secara profesional dapat menerapkan dan mengembangkan bidang keahliannya.

Program pendidikan (Prodi) D3 perpajakan adalah salah satu dari 3 (tiga) Prodi D3 yang secara struktural berada di bawah Fakultas Ekonomi dan Bisnis Unram. Sebagai program pendidikan yang berbasis Vokasi, Prodi D3 perpajakan dalam menyelenggarakan proses belajar mengajar lebih menekankan pada pendidikan keterampilan. Hal ini dapat dilihat dari kurikulum pendidikan yang digunakan lebih didominasi oleh penyelenggaraan pendidikan keterampilan. Secara nyata dapat dilihat pada banyaknya mata kuliah praktikum yang wajib diprogramkanoleh mahasiswa pada setiap semester.

Secara bertahap dan berkelanjutan Prodi D3 Perpajakan telah melakukan perbaikan atas kurikulum pendidikan yang digunakan agar dapat menghasilkan outcome (lulusan) yang siap pakai sesuai kebutuhan pasar kerja. Untuk tujuan yang sama, Prodi D3 Perpajakan telah beberapa kali mengadakan studi banding ke Perguruan Tinggi/ Universitas yang juga mempunyai dan menyelenggarakan program pendidikan Vokasi, terutama ke Perguruan Tinggi /Universitas yang dianggap lebih maju dan mempunyai pengalaman lebih luas dalam menyelenggarakan Prodi Perpajakan

Penyelenggaraan Program Pendidikan D3 Perpajakan di Kota Mataram bukan tidak mempunyai keterbatasan. Keterbatasan pertama adalah pada tenaga pendidik, terutama tenaga dosen tetap yang mempunyai kriteria sarjana Vokasi dengan kompetensi perpajakan. Untuk mengatasi hal ini Prodi D3 Perpajakan menggunakan tenaga praktisi dengan kompetensi yang sama dan melaksanakan kerjasama dengan kantor pajak (DJP Nusa Tenggara dan juga KPP sepulau Lombok). Keterbatasan kedua, adalah bahwa Prodi D3 Perpajakan merupakan pilihan kedua bagi calon mahasiswa karena seleksi masuk ke Prodi D3 Pajak hanya melalui jalur test mandiri yang dilaksanakan setelah jalur SMNPTN dan SBNPTN. Ini tentu saja sangat berpengaruh pada mutu input (mahasiswa Baru) yang diterima oleh Prodi D3 Perpajakan.

Sejauh mana kemajuan proses belajar mengajar yang diselenggarakan oleh Prodi D3 Perpajakan secara keseluruhan akan tergambar pada sejauh mana lulusan dapat memberikan kontribusinya pada masyarakat terkait dengan manfaat bidang keahlian /keterampilan yang diperoleh pada saat kuliah. Secara nyata keberhasilan penyelenggaraan proses belajar mengajar Prodi D3 Perpajakan dapat diukur dari beberapa indikator, antara lain:

a. Apakah setelah berakhirnya proses pendidikan, alumni Prodi D3 Perpajakan akan dapat langsung terserap dalam pasar kerja , dalam arti berapa lama waktu tunggu yang dibutuhkan alumni untuk masuk ke pasar kerja. Tentu saja semakin singkat waktu tunggu memberikan indikasi semakin baik proses belajar mengajar yang telah diselenggarakan

b. Apakah keterampilan yang sudah dimiliki Alumni Prodi D3 Perpajakan sudah memadai dan sesuai dengan kebutuhan pasar kerja? Hal ini dapat diukur dari tingkat kepuasan yang dirasakan oleh para pengguna lulusan (Stakeholder)

c. Berapa banyak para alumni Prodi D3 Perpajakan yang sudah bekerja sesuai atau masih berkaitan dengan kompetensinya. Semakin besar persentase ini menunjukkan proses pendidikan semakin baik.

Studi Pelacakan Alumni (Tracer Study) diharapkan dapat dilaksanakan secara berkala (Setiap tahun ) dan berkelanjutan, selain untuk memberikan gambaran tentangkeberadaan lulusan (Alumni) dan dapat menjawab pertanyaan-pertanyaan di atas, juga dapat berguna sebagai umpan balik (Feed-back) bagi institusi pendidikan di perguruan tinggi. Demikian juga dengan Prodi D3 Perpajakan, studi pelacakan alumni merupakan saranan untuk melakukan evaluasi terhadap proses pendidikan guna dapat 
melakukan perbaikan-perbaikan ( terutama kurikulum pendidikan ) agar kompetensi lulusan dapat berkembang sesuai kebutuhan pasar kerja sehinggadi masa yang akan datang mampu mencetak lulusan yang berkompeten yang mampu bersaing di dunia kerja.

Keberhasilan Pendidikan Tinggi adalah aspek relevansi, yaitu ketika mampu menghasilkan lulusan yang memiliki daya saing dan siap berkiprah dalam pembangunan. Daya saing lulusan yang ditunjukkan melalui masa tunggu mendapatkan pekerjaan pertama, keberhasilan lulusan berkompetisi dalam seleksi, dan gaji yang diperoleh. Relevansi (kesesuaian) pendidikan lulusan ini ditunjukkan melalui profil pekerjaan (macam dan tempat pekerjaan), relevansi pekerjaan dengan latar belakang pendidikan, manfaat mata kuliah yang diprogram dalam pekerjaan, saran lulusan untuk perbaikan kompetensi lulusan. Selain itu, relevansi pendidikan juga ditunjukkan melalui pendapat pengguna lulusan tentang kepuasan pengguna lulusan, kompetensi lulusan dan saran lulusan untuk perbaikan kompetensi lulusan.

Tracer Study dapat mengukur dan melacak lulusan Prodi D3 Perpajakan yang tersebar di berbagai instansi dan berbagai tempat kerja sehingga dapat diperoleh indikator yang jelas tentang gambaran lulusan (alumni) dari Prodi D3 Perpajakan

\section{TUJUAN}

1. Untuk mengetahui gambaran lulusan alumni Prodi D3 Perpajakan (lama kuliah ,IPK,Pendapatan pertama Alumni, Masa tunggu untuk mendapatkan pekerjaan pertama).

2. Untuk mengetahui Tanggapan Pengguna terhadap AlumniProdi D3 Perpajakan fakultas ekonomi dan bisnis Universitas Mataram

3. Berapa besar persentase lulusan yang bekerja pada bidang yang sesuai dengan keahliannya

\section{TELAAH LITERATUR DAN PENGEMBANGAN HIPOTESIS}

\section{Kebutuhan Dunia Kerja}

Memasuki abad ke 21 yang ditandai oleh libelarisasi perdagangan diperlukan upaya sungguh-sungguh untuk meningkatkan kualitas sumber daya manusia (SDM) yang benar-benar siap menghadapi persaingan global yang makin terbuka. Permasalahan yang dihadapi lulusan PTN maupun PTS (SDM) di Indonesia adalah ketidaksiapan saat akan memasuki dunia kerja. Hal ini menjadi tantangan bagi dunia pendidikan di Indonesia agar mampu menciptakan tenaga kerja yang profesional sehingga SDM Negara Indonesia mampu bersaing dengan SDM negara lain seperti Malaysia, Singapura, dan Filipina. Oleh karena itu, tuntutan untuk berani melakukan inovasi dan bekerja sungguh-sungguh untuk mempersiapkan sumber daya manusia masa depan yang sudah terdidik untuk bersaing dalam dunia kerja harus ditindaklanjuti. SDM yang diinginkan di era globalisasi ini tidak hanya sebagai pekerja, tetapi juga sebagai wirausahawan (entrepreneurs). Sejalan dengan kebijakan pemerintah dalam hal ini Departemen Pendidikan Nasional, maka proses pendidikan di perguruan tinggi harus memperhatikan lingkungan dan tuntutan kebutuhan dunia kerja, khususnya dunia usaha dan dunia industri, terhadap SDM yang profesional.

Dunia kerja pada masa mendatang akan menjaring secara selektif calon tenaga kerja yang benar-benar profesional pada bidangnya, oleh karena itu salah satu tantangan utama bagi lulusan perguruan tinggi adalah mempersiapkan diri sebaikbaiknya sebelum memasuki dunia kerja. Upaya peningkatan SDM khususnya dalam pendidikan tinggi adalah melalui program Co-Op (Co-Operative Education), RAPID (Riset Andalan Perguruan Tinggi dan Industri) dan program riset unggulan lainya yang 
merupakan sarana penting bagi pengembangan diri dan kemampuan berwirausaha serta kemandirian secara profesional bagi lulusannya. Untuk menghadapi tuntutan tersebut, Direktur Jenderal Pendidikan Tinggi telah menyatakan bahwa salah satu tujuan utama di bidang Pendidikan Tinggi untuk Pelita VI dan menyongsong tonggaktonggak waktu tahun 2005 dan 2020 adalah; "Penataan Sistem Pendidikan Tinggi agar Lebih Sesuai dengan Kebutuhan Masyarakat dan Pembangunan."

Untuk membangun kemampuan kompetitif bangsa, harus dilaksanakan secara bersama-sama, konvergen dan sinergis dalam hal pengembangan dan pemanfaatan ilmu pengetahuan dan teknologi bagi kesejahteraan bangsa. Komponen pemerintah, perguruan tinggi, dan industri harus bersama-sama menyatukan potensi dalam satu jaringan kerja yang setara dan sederajat untuk melakukan penelitian dan pengembangan secara terorganisir dan sistematik. Apalagi dalam era globalisasi saat ini Indonesia seperti negara berkembang lainnya dihadapkan pada tantangan munculnya persaingan bebas dalam perdagangan antar bangsa. Adanya persaingan bebas ini akan menyebabkan Indonesia "diserbu" atau dihadapkan dengan berbagai macam produk dan teknologi baru dari negara lain.

Dalam kerangka upaya pencapaian daya saing industri, perguruan tinggi dapat berperan lebih dari sebatas penghasil teknologi, akan tetapi perguruan tinggi dapat mengambil peran sebagai „agen perubahan., dan menjadi bagian penting dalam pelaksanaan pPembangunan dan transformasi teknologi. Untuk bisa mengemban peran demikian, suatu jejaring relasi-relasi antara perguruan tinggi dengan penyelenggara pemerintahan (government) dan para pelaku usaha (businessmen/women) perlu dikembangkan.

Tujuan jejaring relasi-relasi antara perguruan tinggi dengan penyelenggara pemerintahan (government) dan para pelaku usaha (businessmen/women) perlu dikembangkan adalah: (1) mewujudkan kerjasama sinergi berkelanjutan antara perguruan tinggi sebagai lembaga penelitian dan pemerintah serta dunia usaha melalui penyeimbangan kebutuhan pasar dan dorongan teknologi; (2) mendorong berkembangnya sektor riil berbasiskan produk-produk hasil penelitian dan pengembangan dalam negeri sendiri untuk menumbuhkan kemandirian perekonomian bangsa; (3) menumbuh kembangkan budaya penelitian yang menghasilkan temuan prospektif dipasaran dan baik dikembangkan menjadi produk industrial yang dapat di produksi dan memberikan manfaat bagi masyarakat

Di era globalisasi terdapat perubahan paradigma di bidang ekonomi dan pendidikan. Saat ini, organisasi telah bergeser menjadi organisasi dengan pola jejaring (network), fokus pada pelanggan serta bersumber pada informasi. Sementara di bidang pendidikan pun telah berubah dari Old Industrial Education menjadi New Entrepreneurial Education. Beberapa perubahan dalam paradigm pendidikan yaitu dulu berfokus pada isi, pembelajaran berpusat ada dosen, dosen bersikap sebagai seorang ahli dan penekanan pada teori, sekarang telah mengalami pergeseran menjadi focus pada proses, pembelajaran berpusat pada mahasiswa, dosen bertindak sebagai fasilitator dan penekanan pada menyelesaikan permasalahan.

\section{Tracer Study}

Seberapa besar lulusan perguruan tinggi mampu berkiprah dalam Pembangunan sesuai relevansi pendidikannya dapat dilakukan upaya penelusuran terhadap lulusannya (Tracer Study). Tracer Study merupakan pendekatan yang memungkinkan institusi pendidikan tinggi memperoleh informasi tentang kekurangan yang mungkin terjadi dalam proses pendidikan dan proses pembelajaran dan dapat merupakan dasar untuk perencanaan aktivitas untuk penyempurnaan di masa mendatang. Hasil Tracer Study dapat digunakan perguruan tinggi untuk mengetahui keberhasilan proses pendidikan yang telah dilakukan terhadap anak didiknya. Bahkan 
dalam program hibah kompetisi maupun akreditasi selalu mempersyaratkan adanya data hasil Tracer Study tersebut melalui parameter masa tunggu lulusan, persen lulusan yang sudah bekerja, dan penghasilan pertama yang diperoleh.

Menurut Schomburg (2003) tujuan utama dari kegiatan Tracer Study adalah untuk mengetahui/ mengidentifikasi kualitas lulusan di dunia kerja, sedangkan tujuan khusus Tracer Study adalah : (1) Mengidentifikasi profil kompetensi dan keterampilan lulusan; (2) Mengetahui relevansi dari pelaksanaan kurikulum yang telah diterapkan di perguruan tinggi dengan kebutuhan pasar tenaga kerja dan pengembangan profesional di dalam kompetensi jurusan; (3) Untuk mengevaluasi hubungan dari kurikulum dan studi di jurusan sebagai pengembangan keilmuan; (4) Sebagai kontribusi dalam proses akreditasi jurusan.

Penelusuran Iulusan (Tracer Study) adalah salah satu hal strategis yang harus dilakukan oleh setiap institusi pendidikan. Setidaknya ada tiga manfaat yang bisa diperoleh dari pelaksanaan kegiatan ini, yaitu: (1) Mengetahui stakeholder satisfaction, dalam hal ini lulusan, terkait dengan learning experiences yang mereka alami, untuk dijadikan alat eveluator kinerja institusi; (2) Mendapatkan masukan yang relevan sebagai dasar pijakan pengembangan institusi, terkait dengan kemampuan bersaing, kualitas, dan working experiences lulusan yang bisa digunakan untuk menangkap kesempatan dan menanggulangi ancaman ke depan; (3) Meningkatkan hubungan lulusan dan almamater, karena apabila dilihat dari pengalaman institusi-institusi pendidikan terkenal, ikatan lulusan dan almamater yang kuat akan banyak membawa banyak manfaat kepada almamater seiring dengan diakuinya kiprah lulusan di masyarakat.

\section{METODE PENELITIAN}

\section{Jenis Penelitian}

Kajian tracer study ini merupakan penelitian deskriptif evaluatif yang berusaha mendeskripsikan profil lulusan dan relevansi materi kuliah kurikulum Prodi D3 Perpajakan melalui pendekatan survei.

Lokasi penelitian ditentukan secara purposive sampling, yaitu penentuan lokasi peneltian di Kota Mataram dengan pertimbangan bahwa kota mataram adalah ibu kota Provinsi yang merupakan tempat pusat kegiatan ekonomi di Provinsi NTB.

\section{Metode Pengumpulan Data}

Metode penarikan sampel dalam penelitian adalah termasuk dalam Nonprobality sampling, artinya pengambilan sampel terpilih didasarkan pada pertimbangan subyektif peneliti. Peneliti dalam hal ini dianggap benar-benar mengetahui tentang karakteristik populasinya, sehingga dalam menentukan sampel peneliti sudah mempertimbangkan dengan kepentingan penelitian. Penentuan sampel respnden dilakkan dengan Accidental Sampling, yaitu teknik penetuan responden sebagai sampel dilakukan dengan menetukan secara sembarang siapa saja alumni Prodi D3 yang kebetulan ditemui dijadikan sampel jika sudah sesuai dengan karakteristik penelitian. Sample Size dalam penelitian ini adalah 60 oarang responden dengan pertimbangan jumlah ini sudah cukup representative dan juga atas dasar perimbangan terbatasnya biaya, waktu dan tenaga yang tersedia.

\section{Metode Analisa Data}

Analisa data dilakukan secara Deskriptif dengan terlebih dahulu dilakukan olah data sederhana serta disajikan dalam bentuk tabel dan diagram. Metode deskriptif dimasudkan karena dalam analisis tidak dilakukan pengujian hipotesis. Jadi dari tabel 
dan diagram yang disajikan dapat diketahui bagaimana profil dari Alumni Prodi D3 Perpajakan dalam kurun waktu Tahun 2016-2018.

\section{HASIL PENELITIAN DAN PEMBAHASAN}

\section{Masa Studi Alumni Progam Studi D3 Perpajakan FEB Unram}

Masa studi atau lamanya mahasiswa Prodi D3 perpajakan menempuh kuliah berkisar antara 3 tahun sampai dengan 5 tahun. Artinya waktu tempuh kuliah tercepat pada jenjang Program Studi D3 Perpajakan adalah 3 tahun Tabel 1. Masa Studi Alumni Prodi D3 Perpajakan Tahun 2014-2017

\begin{tabular}{c|c|c|c}
\hline No. & $\begin{array}{c}\text { Masa Studi Yg Ditempuh } \\
\text { (Tahun) }\end{array}$ & $\begin{array}{c}\text { Jumlah Alumni } \\
\text { (Orang) }\end{array}$ & Prosentase (\%) \\
\hline 1 & 3 Tahun & 57 & 95 \\
\hline 2 & $>3$ th -3.5 th & 2 & 3.33 \\
\hline 3 & $>3,5$ th $-4,0$ th & 1 & 1.67 \\
\hline & Jumlah & 60 & 100 \\
\hline
\end{tabular}

Sumber: Data Primer (diolah)

Tabel diatas menunjukkan bahwa hampir seluruh 95\% Alumni Prodi D3 Perpajakan dapat menyelesaikan kuliahnya tepat waktu,yaitu 3 tahun. Sementara hanya 2 orang (5\%) saja yang menyelesaikan kuliah lebh dari 3 tahun. Dari informasi yang peneliti dapatkan, molornya masa studi dua orang itu disebabkan mereka pernah melaksanakan cuti akademik selama satu semester. Dari sisi ini Program Studi D3 Perpajakan cukup berhasil menyelenggarakan program pendidikannya, karena penyelesaian lama studi yang tepat waktu menunjukkan tidak adanya hambatan dalam proses perkuliahan.

\section{Masa Tunggu Alumni Prodi D3 Perpajakan Mendapat Pekerjaan Pertama.}

Masa tunggu mendapat pekerjaan pertama 40 sampel responden Alumni Prodi D3 Perpajakan Fakultas Ekonomi dan Bisnis Universitas Mataram dapat ditunjukkan seperti tabel berikut.

Tabel 2. Masa Tunggu Mendapat Pekerjaan Pertama Alumni Prodi D3 Perpajakan

\begin{tabular}{l|l|l|l}
\hline No. & \multicolumn{1}{|c|}{ Masa Tunggu } & \multicolumn{1}{|c|}{ Jumlah (Orang) } & \multicolumn{1}{|c}{ Persentase (\%) } \\
\hline 1 & $0-6$ Bulan & 45 & 75 \\
\hline 2 & $>6-12$ Bulan & 12 & 20 \\
\hline 3 & $>12-18$ Bulan & 3 & 5 \\
\hline 4 & $>18-24$ bulan & 0 & 0 \\
\hline & Jumlah & 60 & 100 \\
\hline
\end{tabular}

Sumber: data Primer (diolah)

Dari tabel 4.1.2 diatas terlihat bahwa rentang masa tunggu untuk mendapat pekerjaan pertama dari Alumni prodi D3 Perpajakan relatif singkat. Yaitu 75 persen atau 45 orang dari 60 sampel yang diambil mempunyai masa tunggu 0 sampai denan 6 bulan bahkan ada diantaranya mempunyai masa tunggu 0 bulan , artinya beberapa alumni Prodi D3 Perpajakan sudah mendapat pesanan untuk bekerja di tepat mereka melaksanakan praktek kerja Lapangan seb elum mereka menyelesaikan studi. Sementara ada 20 persen mempunyai masa tunggu mendapat pekerjaan dengan rentang waktu antara lebih dari 6 bulan sapai dengan 12 bulan dan sisanya ada 5 persen mempunyai masa tunggu lebih dari satu tahun. Dengan demikian dapat dikatakan bawa Alumni Prodi D3 Perpajakan sangat cepat terserap di dunia kerja. Hal ini dapat dimengerti karena Prodi D3 Perpajakan sudah merancang kurikulum 
pendidikan yang digunakan untuk mencetak alumninya sebagai tenaga kerja professional yang terampil yang siap masuk bersaing di pasar kerja.

Jenis Pekerjaan Pertama Alumni Prodi D3 Perpajakan

Jenis pekerjaan yang diperoleh oleh 40 sampel responden Alumni Prodi D3 Perpajakan dapat disajikan pada tabel berikut:

Tabel 3. Jenis Pekerjaan Pertama Alumni Prodi D3 Perpajakan

\begin{tabular}{l|l|c|c}
\hline No & \multicolumn{1}{|c|}{ Jenis Pekerjaan } & Jumlah (Orang) & Prosentase(\%) \\
\hline 1 & Pegawai Swasta & 38 & 58.33 \\
\hline 2 & Pegawai Pemerintah (PNS) & 0 & 0 \\
\hline 3 & Pegawai BUMN/BUMD & 15 & 25 \\
& & & \\
\hline 4 & Wiraswasta & 5 & 8.33 \\
\hline 5 & Tenaga Honorer & 2 & 3.33 \\
\hline & Jumlah & 60 & 100 \\
\hline
\end{tabular}

Sumber: Data Primer (diolah)

Tabel 4.13. di atas menunjukkan bahwa jenis pekerjaan yang paling banyak menyerap tenaga kerja yang berlatar belakang pendidikan D3 Perpajakan adalah perusahaan swasta $(58.33 \%)$, selanjutnya penyerap tenaga kerja tebesar kedua adalah perusahaan-perusahaan pemerintah ( BUMN/BUMD ) sebesar 25 persen . kemudian wiraswatadisini adalah tidak satupun tenaga kerja yang berasal dari Alumni D3 perpajakan terserap sebagai pegawai negeri. Ini dapat dimaklumi mengingat pengisian formasi PNS (atau Aparatur Sipil Negara= ASN) untuk Departemen Keuangan dilaksanakan oleh kantor pusat secara on line dengan spesifikasi tertentu.

\section{Penghasilan Pertama Yang Diperoleh Alumni Prodi D3 Perpajakan}

Penghasilan pertama yang diterima oleh Alumni Prodi D3 Perpajakan dalam penelitian ini dibagi menjadi 5 katagori sesuai besarnya penghasilan sepeti pada tabel berikut:

Tabel 4. Besarnya Penghasilan Alumni Prodi D3 Perpajakan FEB Unram

\begin{tabular}{c|c|c|c}
\hline No. & $\begin{array}{c}\text { Jml Penghasilan (Juta } \\
\text { Rupiah) }\end{array}$ & Jumlah (orang) & Prosentase (\%) \\
\hline 1 & $0-1,0$ & 4 & 6.667 \\
\hline 2 & $>1,0-1,5$ & 6 & 10 \\
\hline 3 & $>1,5-2,0$ & 20 & 33,33 \\
\hline 4 & $>2,0-2,5$ & 9 & 15 \\
\hline 5 & $>2,5$ & 21 & 35 \\
\hline & Jumlah & 60 & 100 \\
\hline
\end{tabular}

Sumber : Data Primer (diolah)

Tabel 4.1.4. diatas menunjukkan penghasilan yang diterima oleh Alumni Prodi D3 Perpajakan sangat variatif. Jumlah penghasilan terbesar (Katagori 5) yaitu $>$ Rp2.500.000,00 diterima oleh 21 orang Alumni (35\%), jumlah penghasilan terbesar kedua (>Rp 2.000.000- Rp.2.500.000) diterima oleh 20 orang (33,33\%) Alumni; jumlah penghasilan >Rp1.500.000 - Rp.2.000.000 diterima oleh $35 \%$ Alumni; jumlah penghasilan >Rp1.000.000 - Rp.1.500.000 diterima oleh $10 \%$ Alumni dan jumlah penghasilan terkecil 0 - Rp1.000.000 diterima oleh 6.67\% Alumni. Beragamnya jumlah penghasilan yang diterima oleh Almni Prodi D3 Perpajakan tidak saja disebabkan oleh beragamnya jenis pekerjaan yang mereka peroleh, tetapi juga ditempatkan pada bagian yang berbeda-beda di tempat mereka bekerja. Penempatan di masing-masing bagian ini ada yang relevan dengan keahlian dan kompetensi, tetapi ada sebagian 
besar ditempatkan pada bagian yang tidak relevan dengan keahlian dan kompetensi mereka.

Relevansi Kompetensi Dengan Pekerjaan Alumni

Tabel 5. Relevansi Keahlian dengan Pekerjaan Alumni D3 Perpajakan

\begin{tabular}{l|c|c|c}
\hline No & $\begin{array}{c}\text { Relevansi Keahlian dg } \\
\text { Pekerjaan }\end{array}$ & $\begin{array}{c}\text { Jumlah AlumnI } \\
\text { (orang) }\end{array}$ & Prosentase (\%) \\
\hline 1 & Relevan & 35 & 58.33 \\
\hline 2 & Tidak Relevan & 25 & 41.67 \\
\hline & Jumlah & 40 & 100 \\
\hline
\end{tabular}

Sumber: Data Primer (diolah)

Tabel 4.1.5. di atas menunjukkan bahwa 41.67 persen dari alumni prodi D3 Perpajakan bekerja atau mendapat pekerjaan yang tidak sesuai atau tidak relevan dengan keahlian yan dimliki. Hal ini dapat berdampak luas dengan besarnya gaji, integritas, profesionalisme serta pengembangan diri bagi para alumni itu sendiri.

\section{Tanggapan Pengguna Terhadap Kinerja Alumni Prodi D3 Perpajakan}

Tanggapan pengguna terhadap kinerja Alumni mencakup 7 criteria penilaian pengguna Alumni dapat dikemukakan dalam tabel berikut:

Tabel 4.1.6. Tanggapan Pengguna Terhadap Kinerja Alumni Prodi D3 Perpajakan

\begin{tabular}{c|l|c|c|c}
\hline \multirow{2}{*}{ No } & \multirow{2}{*}{ Kriteia Penilaian } & \multicolumn{3}{|c}{ Tanggapan Pengguna } \\
\cline { 3 - 5 } & & Sangat Baik & Baik & Kurang Baik \\
\hline 1 & Integritas & $25 \%$ & $75 \%$ & - \\
\hline 2 & Profesionalisme & $25 \%$ & $75 \%$ & - \\
\hline 3 & Kemampuan Bahasa Inggris & - & $25 \%$ & $75 \%$ \\
\hline 4 & Penggunaan TI & $50 \%$ & $25 \%$ & $25 \%$ \\
\hline 5 & Komunikasi & $50 \%$ & $50 \%$ & - \\
\hline 6 & Kerjasama Tim & $25 \%$ & $75 \%$ & - \\
\hline 7 & Pengembangan Tim & $25 \%$ & $75 \%$ & - \\
\hline
\end{tabular}

Sumber: Data Primer (diolah)

Tabel 4.1.6. di atas menunjukkan bahwa tanggapan pengguna terhadap kineja secara umum cukup baik. Secara terinci tangapan perngguna pada masing-masing criteria dapat dikemukakan sebagai beikut.

\section{Integritas Alumni Prodi D3 Perpajakan}

Dari tabel di atas terlihat bahwa tanggapan pengguna terhadap integritas Alumni Prodi D3 Perpajakan mayoritas baik, yaitu $75 \%$ dari pengguna menilai baik dan $25 \%$ menilai integritas yang dimliki Alumni Prodi D3 Perpajakan sangat baik. Sedangkan tangapan pengguna yang memberikan penilaian integritas Alumni Cukup Baik tidak ada. Tentu saja hal ini sangat membagakan karena integritas yang baik merupakan langkah awal atau syarat mutlak untuk bisa bersikap profesonal dalam melaksanakan tugas sebagai pegawai yang baru masuk ke dunia kerja.

\section{Profesionalisme Alumni Prodi D3 Perpajakan}

Profesionalisme merupakan sikap yang harus dimiliki dan dilaksanakan oleh seseorang agar hasil yang diperoleh dalam menjalankan tugas ataupun usahanya secara optimal. Seseorang yang professional akan bekerja dan menjalankan usahanya sesuaidengan profesinya, mengutamakan kepentingan tugasnya diatas kepentingan pribadi, keluarga atapun golngan. Tanggapan pengguna terhadap profesonalisme Alumni Prodi D3 Perpajakan menunjukkan bahwa $75 \%$ menyatakan baik bahkan $25 \%$ memberikan penilaian sangat baik (lihat tabel 4.1.6.2 di atas) 


\section{Kemampuan Bahasa Inggis}

Bahasa inggris merupakan bahasa internasional, bahasa standar, bahasa yang digunakan sebagai indicator komunikasi internasional sehingga wajib dipelajari oleh setiap orang di dunia. Kemampuan Bahasa Inggris dijadikan sebagai salah satu ukuran baik-buuknya kinerja. Oleh karena itu tidak keliru apabila banyak instansi maupun perusahaan di Indonesia mewajibkan karyawannya untuk meningkatkan kemampuan bahasa inggrisnya hingga pada level tertentu. Di dunia pendidikan mulai dari tingkat sekolah dasar bahkan Taman kanak-kanak sampai tingkat Perguruan Tinggi mata pelajaran bahasa inggris wajib dimasukkan dalam kurikulumnya. Bagaimana imengambarkan masih lemahnya kemampuan bahasa inggris Alumni Prodi D3 Perpajakan, karena $75 \%$ pengguna Alumni menyatakan bahwa kemampuan bahasa inggris Alumni Prodi D3 Perpajakan kurang baik dan hanya $25 \%$ dari pengguna memberi penilaian kemampuan bahasa inggris Alumni pada level Baik.

\section{Penggunaan IT}

Tidak bebeda dengan bahasa Inggris, diera Digital ini semua karyawan baik diperusahaan maupun di instansi pemerintah harus mahir dalam penggunaan IT, karena bila tidak harus siap untuk ketingalan informasi diberbagai bidang. Tidak hanya itu, penggunaan IT saat ini sudah merambah ke semua aktivitas seperti penghitungan pembayaran pelaporan sehingga wajib bagi setiap karyawan untuk mampu dalam penggunaan IT. Tanggapan pengguna terkait kemampuan Alumni Prodi D3 pajak dalam penggunaan IT seperti terlihat pada tabel di atas adalah 50 persen pengguna menyatakan sangat baik; 25 persen menyatakan baik dan ada $25 \%$ pengguna menyatakan kurang baik. Data barangkali dapat dijadikan bahan kajian untuk menambah porsi praktek computer baik intra maupun ekstra kurikulum oleh Lembaga Prodi D3 Perpajakan,

\section{Komunikasi, Kerjasama Tim dan Pengembangan Diri Alumni.}

Untuk tiga criteria penilaian kinerja Alumn ini bersifat internal pribadi masingmasing alumni karena ketiganya tidak tekait dengan kurikulum pendidikan pada prodi D3 Perpajakan. Tanggapan pihak pengguna alumni terhadap kinerja alumni prodi D3 Perpajakan berdasakan tiga criteria tersebut dapat dikemukakan sebagai berikut:

1. Komunikasi: 50 persen pengguna menyatakan sangat baik dan 50 persen menyatakan baik terhadap kinerja Alumni Prodi D3 Perpaakan.

2. Kerjasama Tim: 25 persen pengguna menyatakan sangat bak dan 75 ppersen menyatakan baik terhadap kinerja Alumni Prodi D3 Perpajakan.

3. Pengembangan Diri Alumni: 25 persen pengguna menyatakan sangat baik dan 75 persen menyatakan baik terhadap kinerja Alumni Prodi D3 Perpajakan

Dari analisa hasil di atas terihat bahwa Alumni Prodi D3 Perpajakan dapat menyelesaikan studinya secara tepat waktu, hal ini terbukti bahwa hampir seluruhnya (95 \%) alumni Prodi D3 perpajakan selesai dalam waktu 3 tahun. Keberhasilan mahasiswa dalam menyelesaikan studinya tepat waktu menggambarkan keberhasilan bagi institusi Program Studi D3 perpajakan dalam mengelola system perkuliahan. Pengelolaan system perkuliahan merupakan salah satu variabel yang menentukan kualitas outcome selain variable kualitas input (masukan) yaitu mahasiswa itu sendiri. Pada variable system perkuliahan ini termasuk antara lain sarana dan prasarana pendidikan, kurikulum dan Sumberdaya manusia (Dosen dan tenaga administrasi).

Untuk masa tunggu Alumni Prodi D3 Perpajakan mendapat pekerjaan pertama relative singkat yaitu 75 persen memperoleh pekerjaan pertamanya paling lama 6 bulan, bahkan beberapa alumni sudah mendapat pesanan untuk bekerja sebelum mereka tuntas menyelesaikan studi. Kondisi ini juga menunjukkan keberhasilan institusi dalam mengelola system perkuliahan. Harus diakui bahwa Prodi D3 Perpajakan 
sampai penelitian ini dilaksanakan masih menggunakan kurikulum yang belum direvisi karena mengandung muatan praktek yang kurang dari batas minimal untuk muatan praktek program pendidikan vokasi, yaitu 60 persen.

Pekerjaan pertama alumni prodi D3 Perpajakan sebagian besar (62,5\%) adalah pegawai swasta dan bagian terbesar kedua $(22,5 \%)$ adalah pegawai atau karyawan BUMN/BUMD termasuk karyawan Bank. Ini dapat dimengerti karena Program Studi D3Perpajakan mempunyai hubungan kerjasama dengan Perusahaan-perusahaan baik itu milik swasta maupun milik pemerintah terutama kerjasama dalam hal praktek perpajakan dimana perusahaan-perusahaan itu sepakat untuk ditempati mahasiswa melakukan praktek perpajakan atau magang (PKL).

Penghasilan pertama Alumni Prodi D3 Perpajakan cukup memadai walaupun masih variatif. Hal yang patut diapresiasi adalah ada 45 persen Alumni Prodi D3 Perpajakan yang gaji atau penhasilanpertamanya diatas Rp2.000.000 perbulan .Penghasilan yang cukup besar ini merupakan insentif yang dapat memotivasi para pekerja Alumni Prodi D3 Perpajakan untuk bisa mempnyai integritas yan tinggi dan bisa bertindak secara professional sehingga proses pengembangan diri untuk menjadi lebih professional lagi bisa lebih cepat. Sementara gaji yang relatif rendah ( dibawah Rp.1.500.000,-/perbulan ) masih diperoleh oleh sebagian kecil Alumni Prodi D3 Perpajakan ( $20 \%$ dari jumlah Alumni) dan ada 35 persen yang memperoleh gaji atau penghasilan pada level sedang, yaitu Rp.1.500.000 - <Rp.2.000.000 setiap bulannya. Sebagai gaji pertama, ada alumni yang meangap ini sebagai batu loncatan untuk mendapatkan pengalaman kerja untuk menuju pada pekerjaan yang lebih baik, lebih sesuai dengan keahlian dan kompensi yang dimiliki.

Relevansi keahlian dengan jens pekerjaan dari alumni Prodi D3 Perpajakan memang masih kurang menyenangkan karena ada 57,5 persen dari jumlah alumni Prodi D3 Perpajakan yang bekerja pada bagian yang tidak relevan dengan kompetensi atau keahlian mereka.Semoga pekerjaan pertama ini hanya sebuah batu loncatan menuju pekerjaan yang lebih sesuai dengan keahlian dan kompetensi mereka sehingga mereka nantinya dapat memperoleh penghasilan yang lebih tinggi dan lebih cepat dalam proses pengembangan diri.

Tanggapan pengguna (user) terkait kinerja dari Alumni Prodi D3 Perpajakan adalah baik, karena dari isian kuesioner dari para pengguna alumni, 6 dari 7 kriteria menyatakan baik dan sangat baik, kecuali pada criteria kemampuan bahasa inggris, ada 75 persen pengguna menyatakan kurang baik. Hal ini setidaknya menjadi pemikiran dan pertimbangan dari para pengelola Prodi D3 Perpajakan sebagai bahan perbaikan kurikulum pada program Studi D3 Perpajakan di masa datang. Selain itu yang pelu mendapatperhatian juga dalam studi ini adalah ada 25 persen pengguna yang menyatakan kemampuan IT alumni kurang baik. Kemampuan IT adalah suatu kemampuan mendasar yang harus dimiliki oleh semua alumni Prodi D3 Perpajakan karena di era Digital ini hampir semua kegiatan administrasi perpajakan dilakukan secara On-line, mulai dari proses penghitungan, pembayaran atau penyetoran sampai proses pelaporan (E-SPT, E-filling).

Selain itu pada bagian space saran pada kuesioner ada saran dari pengguna alumni D3 Perpajakan untuk dilaksanakan kursus atau pelatihan Brevet Perpajakan di luar kurikulum yang ada. Saran ini perlu ditanggapi terutama untuk mengkompensasi atau menutupi kurangnya muatan praktek pada kurikulum Prodi D3 Perpajakan yang masih digunakan sampai saat laporan penelitian ini dibuat. Selain itu secara formal sertifikat Brevet marupakan syarat tambahan untuk para Alumni D3 Perpajakan agar dapat mewakili perusahaan tempat mereka bekerja dalam kepengurusan administrasi pajak ke Kantor Pelayanan Pajak (KPP). 


\section{SIMPULAN}

berikut :

Dari pembahasan tersebut di atas dapat ditarik beberapa kesimpulan sebagai

1. Hampir seluruh Alumni D3 Perpajakan menmpuh masa studi 3 tahun. Ini menunjukkan mahasiswa dalam melaksanakan perkuliahannya sesuai dengan rencana. Selain itu masa studi yang tepat waktu ini adalah indicator keberhasilan pengelolaan Program Studi D3 Perpajakan.

2. Masa tunggu yang relative singkat untuk mendapat pekerjaan pertama dari para alumni menunjukkan bahwa keahlian (skill) para alumni D3 perpajakan khususnya dalam bidang perpajakan masih sangat dibutuhkan pasar kerja. Namun demikian masih banyaknya Alumni D3 perpajakan yan bekerja pada bidang yang tidak sesuai dengan keahlian mereka menginidikasikan bahwa pasar kerja juga terbatas dalam arti jumlah permintaan pada setiap segmen pasar kerja tidak dapat menampung semua penawaran kerja alumni D3 Perpajakan.

3. Penilaian pengguna terhadap kinerja lulusan prodi D3 Perpajakan dipandang dari 6 kriteria: Integritas, Profesionalisme, Penguasaan Teknologi informatika (IT), Komunikasi, Kerjasama Tim dan Penembangan Diri adalah baik dan sangat baik kecuali dalam Kemampuan Bahasa inggris yang dinilai masih kurang baik. 


\section{DAFTAR PUSTAKA}

Ahmad Seng (2009). "Relevansi Pendidikan Tinggi dengan Kebutuhan Dunia Kerja Harapan dan Tantangan". Diakses dari http://malutpost.com pada tanggal 6 Maret 2009.

Dhyah Styorini, 2012, Kajian Relevansi Kemampuan Penguasaan Bahasa Asing Dan Teknologi Informasi Lulusan Program Studi Akuntansi Fe Uny Tahun $2004-2011$

Schomburg, Harald (2003). Handbook for Graduate Tracer Study. Moenchebergstrasse Kassel, Germany: WisseschaflichesZentrumfürBerufs- und Hochschulforschung, Universität Kassel

Sugiyono. 2005.Statistik untuk Penelitian, Bandung: CV Alfabeta 